\title{
Travelling Pattern and Preferences \\ of the Arab Tourists in Malaysian Hotels
}

\author{
Zulkifli Ibrahim \\ Faculty of Hotel and Tourism Management, Universiti Teknologi MARA \\ Shah Alam, 40450, Selangor, Malaysia \\ Tel: 60-3-5543-5688 E-mail: zul_ibrahim01@yahoo.com.my
}

\author{
Mohd Salehuddin Zahari \\ Faculty of Hotel and Tourism Management, Universiti Teknologi MARA \\ Shah Alam, 40450, Selangor, Malaysia \\ Tel: 60-3-5543-5680 E-mail: salehuddinm@yahoo.com
}

Maimunah Sulaiman

Faculty of Hotel and Tourism Management, Universiti Teknologi MARA

Shah Alam, 40450, Selangor, Malaysia

Tel: 60-3-5543 -5671 E-mail: maimun830@salam.uitm.edu.my

Zulhan Othman

Faculty of Hotel and Tourism Management, Universiti Teknologi MARA

Shah Alam, 40450, Selangor, Malaysia

Tel: 60-3-5522 -5853Ｅ-mail: zulhan@salam.uitm.edu.my

Kamaruzaman Jusoff (Corresponding author)

Yale University, Yale Tropical Resources Institute, School of Forestry \& Environmental Studies

205, Prospect St, New Haven, CT 06511, USA

Tel: 20-3-676-7761 E-mail: jusoff.kamaruzaman@yale.edu

The research is funded by Universiti Teknologi MARA, Malaysia (Sponsoring information)

\begin{abstract}
This study examined the travelling pattern of the Arab tourists in relation to their purpose and frequency of visit, duration of stay, travelling companions and activities engaged in during the vacation. The preferences of these tourists for hotel restaurant food and front office attributes while staying in selected five star hotels were also investigated. The result demonstrated that Arab tourists came to Malaysia mostly for a vacation with their spouse and children, and the majority of them were visiting for the first time. The major activities engaged in were sightseeing and visiting interesting places plus other activities such as shopping, visiting theme parks and beaches. The average length of stay was from 3-10 nights. The findings also revealed that besides other type of cuisines, home cooking (Arab cuisine) was preferred by the Arab tourists. Similarly, the Arab tourists preferred to have a fast check in, friendly and personalized service and courtesy by front office personnel upon arrival at the hotel. The ability to communicate in and understand the Arabic language among the front office personnel also had a profound effect on their fondness. In turn, a strong relationship among government, local authorities, private agencies and hotel operators should be fostered to capture a larger share of this market segment
\end{abstract}

Keywords: Travelling pattern, Preferences, Arab tourists, Hotel management, Food and beverages, Front office 


\section{Introduction}

The global impact from the September 11 terrorist attacks on the United States in 2001 and the subsequent unforeseen terrorism has affected the world tourism industry (Hamarneh \& Steiner, 2004). These unexpected events have had a significant impact on the travelling mood of international tourists particularly the Arabs from the Gulf region and Muslim communities. The Arabs and the Muslim communities have been blamed for being responsible for terrorism. Consequently, the feeling by Arabs of being misunderstood and unwelcome in non-Muslim countries has increased. The travelling policy against the Arab tourists has become more rigid in many countries especially in the United States, United Kingdom, Australia and European nations. Over-reactions, ignorance and chauvinism in those countries have forced many Arabs tourists to look for new frontiers and change their traditional holiday destinations to other countries (Hamarneh \& Steiner, 2004). As a result, Malaysia as well as other Asian countries was found to be one of the favourite alternative vacation destinations for the Arabs. Malaysia as a Muslim country shares a common Islamic culture and tradition and the Muslim Arabs feel safer in terms of security, food, shopping and religious obligation.

Lately, the number of tourist from the Gulf region has risen over the last few years. As reported, the influx of Arab tourists to Malaysia reached a total of 126,000 in 2004; 150,000 in 2005 and 200,000 in 2006 (New Straits Time, 2007). This is further strengthened as the West Asian market is considered as high yield expenditure with an average expenditure of RM3, 397.4 per capita and an average stay of 13.7 nights compared to tourists from other countries. In fact, the Middle Eastern markets turned out to be in the top for per capita expenditure in the year 2003, despite a slight reduction in the Arab tourists' arrivals. However, the decline was expected due to the SARS outbreak and the haze. The income from the influx, outstanding expenditure and spending power among the Arabs tourists have contributed to a significant impact on the Malaysian economy. Such contributions have made the Middle East one of the most important market segments for the Malaysian tourism industry. In line with this new pattern, Tourism Malaysia, tour operators as well as hotel operators should take this opportunity to promote tourism products such as attractions, cultural events, shopping facilities, hotels and services to capture a larger share of this market segment. In other words, understanding the travelling patterns enables the hotel operators in particular to comply with the needs of these tourists, which in turn enhances their satisfaction and leads to repeat visits to this country.

To date, most of the studies pertaining to Arab tourists were undertaken in developed countries (Ritter, 1989; Din, 1989; Graburn, 1997; Houellebecq, 2001). Ritter (1989) investigated the differences between the travel behavioural pattern of Muslims and Arabs and those of their European counterparts. Din (1989) looked on the Islamic concept of tourism while Graburn (1997) discussed the Islamic concept of travel related to the sacred goal of submission to the ways of God as opposed the commercial goals of mass travel that stresses profit maximization and customer satisfaction. Houellebecq (2001) examined the travelling pattern of pilgrims during the hajj season. However, very limited analysis on the behavioural patterns and preferences among these Arab tourists related to Malaysia has been undertaken. This study therefore aimed to identify the travelling patterns of the Arab tourists in relation to their purpose and frequency of visit, duration of stay, travelling companions and activities engaged in. In addition, their preferences regarding hotel restaurant food and front office attributes while staying in Malaysian hotels were also investigated.

\section{Methodology}

As this study looked at the travelling patterns of the Arab tourists to Malaysia, the triangulation approach (quantitatitive and qualitative) was used as it gives in depth information on issues investigated (Cavana and Dalahaye, 2001). In the quantitative approach, the target population was the Arab tourists who were staying in five star hotels. The reason for choosing five star hotels was based on the information obtained from the Malaysia Hotel Association (2004) and Tourism Malaysia (2004) that the majority of the Arab tourists were staying in these star rated hotels. Nevertheless, despite many hotels falling into this category in Malaysia, the researcher found difficulties in collecting data from the whole country. A report gathered from Tourism Malaysia indicated that most of the Arabs tourists mainly visited Kuala Lumpur compared to other cities in Malaysia (Tourism Malaysia, 2003). Based on this information plus the other mentioned constraints, it was decided to collect the data from the hotels situated in the Kuala Lumpur Golden Triangle. This area is one of the most famous areas for business, commerce and shopping in the heart of Kuala Lumpur, and most importantly, this area is famous for international chain hotels. Most of the five star hotels like Shangri-la, Parkroyal, Mutiara, Sheraton, Ritz Carlton, Renaissance and many more are located within the vicinity of four kilometres. According to Tourism Malaysia (2006), most of the international hotels in this area are very popular among the Arab tourists compared to other hotels in other parts of Kuala Lumpur.

With regard to the instrument, a few factors were taken into consideration prior to its development. The first relates to the language in the instrument. So as to facilitate a better understanding among Arab tourists, it was decided to develop the questionnaires both in English and the Arabic language. The reasons for this were that some of the Arab tourists were believed to understand the English language and some may have a poor understanding of English. The English version was first edited and then translated and written in Arabic by an Arab language lecturer from the Language Centre of Universiti Teknologi MARA (UiTM) who is fluent in both English and Arabic. The questionnaire comprised three 
sections. The first section was developed to gather demographic information from the respondents. Questions were designed using nominal scales and focussed on respondents' age, gender, marital status, profession and country of origin. The second section was created to record information concerning the travelling pattern of the Arab tourists. Questions such as purpose of visit, frequency of visit, duration of stay were included in this section. It was felt that the inclusion of these attributes would provide significant results about the travelling pattern among these tourists to Malaysia. The third section comprised questions relating to the preferences of the respondents towards hotel restaurant food and front office attributes. This section required respondents to rank the answers.

On the data collection process, letters seeking approval to undertake the study were sent to the Human Resource managers at each hotel located in the Kuala Lumpur Golden Triangle. Out of fourteen hotels, only five hotels granted permission. The five hotels were Berjaya Time Square Hotel and Convention Centre, The Ritz-Carlton, Mandarin Oriental Hotel, JW Marriott Hotel and Renaissance Hotel. Subsequent to that, meetings with Human Resource managers at the participating hotels were held as well to explain in detail the instructions, procedure and how the questionnaires were to be administered by the front office personnel. All the respective Human Resource managers were given a time of around one month (August 2005) to disseminate the questionnaire. Subsequently, the researcher personally collected the filled questionnaires from the respective hotels. Out of 321 questionnaires disseminated, 130 useable questionnaires were collected. The questionnaires were then coded using the Statistical Package for Social Science (SPSS for Window V.16.).

For qualitative information, short structured interviews with selected Arab embassies were undertaken. This is one of the best ways to obtain insights into and clarification of the information of the overall travelling pattern of the peoples from the Arab regions. The selected Embassies were Saudi Arabia, Kuwait, Syria, and United Arab Emirates. These embassies were chosen because most of the Arab tourists visiting Malaysia are from those countries as reported by Tourism Malaysia (2006). After permission was granted from all attachés, interview sessions were conducted from $3{ }^{\text {rd }}$ September to $17^{\text {th }}$ September 2005 at each respective embassy. The information gathered was then transcribed.

\section{Results and discussion}

\subsection{Demographic profile}

Frequencies related to demographic profile of the respondents were computed. Results revealed that the majority of the Arab tourists who visited Malaysia in this study were married with families which made up 77.7 percent $(\mathrm{n}=101)$ of the sample against 22.3 per cent $(\mathrm{n}=29)$ who were single. The ages ranged from 20 to above 60 years. The highest proportion was between the ages of 30 to 59 years which represents 65.4 percent $(n=85)$ of the total respondents followed by those aged 20 to 29 years or 30 percent $(n=39)$ and 4.6 per cent $(n=6)$ respondents over 60 years of age. It could be said from this finding that most of the Arabs tourists visiting Malaysia were among the youth to the middle aged groups compared to older groups

More than forty percent ( 43.8 percent, $\mathrm{n}=57$ ) of the respondents were in the occupations classified as administrative, 40.0 percent $(n=52)$ were in professional and technical occupations, and 5.4 percent $(n=7)$ were students of higher institutions. The rest of the respondents were retirees ( 4.6 percent, $n=6)$, sales and clerical, 3.8 percent $(n=5)$, and others ( 2.3 percent, $\mathrm{n}=3$ ). All in all, the highest proportion of respondents came from among the professional / technical and administrative (83.8 percent, $\mathrm{n}=109$ ). This result fitted with the result of the previous studies (Crompton, 1979; Yuan \& McDonald, 1990; and Basala \& Klenosky, 2001) which indicated that the pattern and frequencies of travelling are among those with high disposable income.

In regard to country of origin, the highest percentage of respondents were from Saudi Arabia (46.9 percent, $\mathrm{n}=61$ ) followed by United Arab Emirates (13.1 percent, n=17) and Kuwait (9.2 percent, n=12) compared with other neighbouring countries such as Syria, Lebanon, Egypt, Iraq, Qatar, Oman, and Yemen. This result was in line with the Tourism Malaysia Report (2006) that the majority of Arabs coming to this country were from the oil producing countries in the Middle East region. In other words, the disposable income of people from these rich oil nations is higher as compared to other Arab nations. The small percentage of the Arab tourists (around 2 percent) from Iraq and Lebanon was probably due to the internal conflict and political instability in these countries.

\subsection{Travelling pattern}

Some significantly meaningful results were obtained related to the travelling pattern of the Arab tourists to Malaysia. It appeared that the main purpose of travelling was for a holiday (83.8 percent, $\mathrm{n}=109)$ compared to business purposes $(8.5$ percent, $\mathrm{n}=11)$, visiting friends and relatives ( 2.3 percent, $\mathrm{n}=3$ ) and other purposes ( 5.4 per cent, $\mathrm{n}=7$ ). The majority of them ( 88.5 percent, $n=115)$ were visiting this country for the first time, followed by 7.8 percent $(n=10)$ visiting for the second time and 3.3 percent $(n=5)$ had visited more than three times. In view of the fact that the majority of Arab tourists visited Malaysia for the purpose of a holiday, it is not surprising to see 40.8 per cent $(n=53)$ of respondents in this study staying more than 10 nights over represented those who stayed between 7-9 nights (15.4 percent, $\mathrm{n}=20)$, 4-6 nights (32.3 percent $(n=42)$, and fewer than 3 nights $(11.5$ percent, $n=15)$. Therefore, on average the length of stay among the Arabs 
tourists in Malaysia was 6 nights. This period is considered by the economists to be good enough to generate a substantial amount of revenue to the country through various tourist activities (Pearce, 1983).

On travelling companion, 56.9 percent $(\mathrm{n}=74)$ of the Arab tourists in this study travelled with their spouse and children, 23.1 percent, $n=30$ travelled with their spouse and relatives, 10.0 percent, $(n=13)$ travelled with business associates, 5.4 percent $(n=7)$ travelled with friends, 3.1 percent $(n=4)$ travelled alone and 1.5 percent $(n=2)$ with other travelling companions. It could be contended that significant proportions of Arab tourists prefer to travel with companions as it probably provides them with security and eases some of the communication problems. This notion supports Polunin, (1989) who noted that travelling within a group provides security. It is also in line with Islamic teaching that encourages individuals especially women and children to travel with muhrim or blood relations. On the other hand, the major activities engaged in were sightseeing and visiting interesting places (80.8 percent, $\mathrm{n}=105)$, visiting theme parks $(10.0$ percent, $\mathrm{n}=13)$, shopping ( 6.9 percent, $\mathrm{n}=9$ ) and other activities ( 2.3 percent, $\mathrm{n}=3$ ).

\subsection{Preferences in hotel restaurant food}

In the context of this study, food preferences were simply defined as the selection of the type of food preferred by the respondents from choices available to them. In relation to this, the Western food was ranked as the most popular choice among the Arab tourists (rank 1). This was not surprising as Western food is internationally acceptable and served in most of the hotels. This was followed by Indian food (rank 2). The Indian food was favoured probably because it had a slight similarity with some of the Arab food. Surprisingly, in this analysis the Middle Eastern food was ranked third in the echelon (rank 3). However, when checking the number of hotels offering Middle Eastern food, only two hotels were found to be offering such food. Malay, Chinese and other food (rank 4) were also found to be slightly acceptable to the Arabs tourists though not as popular as Western, Indian and Middle Eastern food.

On other food attributes, factors related to quality of food (rank 1) were ranked first by the respondents followed by variety and choices of Arabic food (rank 2), menu for diet-conscious (rank 3) and provision for children in the menu (rank 4). What could be said of this result is that the Arab tourists were willing to spend as long as the quality of food met their expectations. In addition, they also expected to see some of the Arab delicacies including children's delicacies on the hotel restaurant menu.

\subsection{Preferences in front office attributes}

A few questions were posed to measure Arab tourists' preferences in front office attributes upon arrival at the hotel. Fast check-in (rank 1) was recognized as the most important attribute by the Arab tourists followed by friendly and personalized services (rank 2), courtesy displayed by bellmen and receptionists (rank 3), and ability of staff to communicate in Arabic (rank 4). From these ratings it could be said that the majority of Arabs tourists preferred to have fast check-in and to be allocated to their rooms, especially after an extensive and long-haul journey. Politeness and courtesy by the front office personnel were also expected by the Arabs tourists. Besides that they also preferred to have front office staff that could communicate or know a little bit of Arabic. All in all, these findings indicated that efficiency, fast service and friendlier staff are expected by most of the Arab tourists upon arrival at the hotel.

\subsection{Qualitative data attributes}

As previously mentioned, a small structured interview with the key informants of selected Arab attachés in Kuala Lumpur were undertaken to validate and strengthen quantitative results. The selected Arab attachés were the Royal Embassy of Saudi Arabia, the Royal Embassy of the United Arab Emirates, the Embassy of the State of Kuwait and the Embassy of the Syrian Arab Republic. Results showed that the four key informants from each embassy generally shared the same views with regard to the overall travelling pattern of the Arabs to Malaysia. Each of them mentioned that most of the Arab tourists frequently travel with family and the majority them are those from the middle aged groups as compared to the older groups. For instance, the key informant, the Saudi Embassy revealed that tourists from the Arab nation were generally middle-aged parents who preferred to bring their children along when travelling. He added that the older Arabs, especially among the Muslims were more likely to devote their life to God and probably were not really interested in travelling abroad except for pilgrimage purposes.

The key informant from UAE embassy emphasized that the majority of Arab women normally travelled with husband or families. Quoted verbatim he said that: "Through my observation, most women in Arab nations always travel with husbands or male relatives. Women are seldom allowed to travel alone. This is especially in the countries near to the Arab Peninsula". This information corresponded well with the quantitative result that there were only 10 percent of women respondents in this study compared to 90 percent of male respondents. In regard to occupations, the key informant of the Saudi Arabian embassy noted that the majority of Arab tourists were among those working for the private or government sector, and businessmen. The same view was given by the key informant of the Syrian and Kuwait embassies. This information again supports the quantitative results which revealed that the highest responses were for occupations of administration, professional and technical work. 
On the reasons for visiting Malaysia, the key informants of the Saudi Arabian Embassy claimed that most of the Arabs travel for a holiday. He noted that the Arabs knew that Malaysia has beautiful scenery and a natural environment. For the newly married, they chose Malaysia as their honeymoon destination. He stated that before September 11, the United Kingdom and the United States had long been popular among the Saudis. However, since the incident, Malaysia has become popular among the Arab nations as this country shares the same religion. On the same note, the key informant of the Syrian Embassy commented that; "Since the Syrian government has actively promoted tourism in the past 10 years, the mood of travelling and visiting overseas countries has increased among the Syrian and the Arab nations. Malaysia offers a lot of opportunity concerning the culture diversity, multiracial society, the ethnic minority and tourists can find the whole of Asia in one country and that is what they are looking for. They know that Malaysia is the Truly Asia thing. They can eat Chinese food, Indian food and Malay food in this country. The travelling pattern of the Arab peoples has changed. The Arabs or the Muslim peoples find difficulty in getting visas for vacations in America, United Kingdom and Europe. The Syrians do not need visas to come to Malaysia and this is one of the most encouraging things"

With regard to the duration of stay, the majority of the Arab tourists were found to be staying in Malaysia for at least five days. This statement was given by most of the key informants. For example, the key informants of Saudi Arabia embassy noted that: "...... as far as I know most Saudi tourists were here on holiday and they stayed in this country for at least five days". In terms of the activities engaged in, the information gathered from the informants supported the quantitative results which indicated that shopping is not a priority among the Arabs who are more concerned with exploring the country. For instance, key informant of the Syrian Embassy quoted: "From the information I gathered, most of the Arabs want to see Kuala Lumpur and surrounding areas. It is nice to discover this Muslim country”. The key informant of the UAE Embassy commented that: "Arabs from UAE do not put shopping as their priority because they can find cheaper products of the same quality in their country. They go abroad for vacation and seeing the country. Of course, in the vacation they will bring back some souvenirs for the family and relatives".

All in all, the information gathered from interviews validated and strengthened the results given by the respondents in the closed ended questions. On the basis on these research findings, it appears that the pattern of Arab tourists coming to Malaysia is mostly for a vacation with spouse and children and the majority of them are visiting this country for the first time. As is the normal practice for every first time vacation, tourists are expecting the get the best experiences over their entire period of their vacation. In response to this, the government, local authorities, related agencies and the public should collectively portray a good image of Malaysia to the tourists. As such, all frequently visited areas by international tourists (historical places, national mosque, national monuments and museums) and other popular spots (airport, railway stations, public eating areas, theme parks, beaches and shopping complexes) should be well maintained and always in a pleasant condition.

As sightseeing is one of the major activities revealed in this study, the cleanliness of the city and surrounding areas therefore should be maintained all time. This is not to say that our local authorities are not concerned with cleanliness, but comments received from the international tourists indicate that they are not satisfied with the level of cleanliness in most of the major cities in Malaysia, especially Kuala Lumpur. Thus, the authorities need to make a greater effort than before to ensure the cleanliness of those places. Another issue of concern is related to public transportation. Although the government and local authorities have provided good public transportation, complaints about the inefficiency of the overall services, dissatisfaction with the dishonest taxi drivers and the reckless bus drivers, and the unfriendliness of public transport personnel still occur and have often been reported by the tourists. The information gathered from interviews with key informants in this study probably supports this notion. This issue is always being brought up in the local media, even by the politicians. Taking one example, Arab tourists complained that taxi fares sometimes were overcharged in Kuala Lumpur and were not equivalent to the distance. With this, the local authorities should take the necessary steps to provide a more efficient service by the local transport and enhance some of the human aspects such as courtesy, honesty, friendliness, knowledge and information through training and courses. Again, this is not to bluntly accuse the local authorities of never taking action on this issue, but it must be done continually. All in all, it could be said that if the matters raised were not being taken care of promptly and always, sooner or later the image of Malaysia in the eyes of Arabs and other international tourists will be tarnished and subsequently hinder the arrival of new tourists and reduce repeat vacations.

The result of this study also shows that the majority of Arab tourists visiting Malaysia are from Saudi Arabia, Kuwait, United Arab Emirates and Syria. With that pattern, the government through the Malaysian Tourism Boards needs to increase what they have done up until now to promote Malaysia to all those countries and make known to them what our country can offer them in relation to tourism products as well as business opportunities. Besides that, the needs, travelling pattern, culture, language and food of these countries need to be further studied so that we will understand what they expect when they visit Malaysia. In addition, other countries such as Iraq, Lebanon, Afghanistan, Turkey, Libya, Yemen and others cannot be ignored as they are also considered as potential markets for Malaysia despite the internal conflicts a number of these countries are still facing. Besides promoting Malaysia as a new tourist destination among the Arab nation countries, the government is also striving to establish this country as the educational hub for the Middle East region. It is 
interesting to note that there were a number of university students who responded to this study. It is argued that university students besides having a holiday are probably coming with the intention of gaining a better understanding of our educational system before pursuing their study here. The interviews with a few Arab students in the International Islamic University presumably strengthened this notion. As evidence the Consul General of Saudi Arabia stated that more than 2000 students from this country are pursuing various fields of study now in Malaysia. In line with this, the government through the Ministry of Education put tremendous effort into organizing the educational expo in Dubai to introduce and promote undergraduate and postgraduate programs in Malaysia.

With regard to food choices, one of the significant findings revealed that besides other types of cuisine, home (Arab) cuisine was preferred by the Arab tourists. Nevertheless, most of the hotels in this study were found not to be offering Arab food in their restaurants. Based on this evidence, hotel operators need to understand in depth, or be more alert to the needs and demands of these groups of tourists pertaining to food. Besides Western and local food, the hotel operators should offer at least three or four of the most popular items of Arab cuisine such as Shawarma, Kebab, falafel, Shish Biryani on the menu, or have an Arab food promotion especially in the peak season when most of these tourists are visiting Malaysia. In line with this notion, some hotels in Kuala Lumpur have taken the initiative in incorporating a few Arab food items in the menu. They in fact hire cooks and chefs from the Middle East during the peak season just to cater to the Arab markets. This smart move has directly encouraged in-house Arab guests to patronise the restaurant and thus increase hotel revenue. In addition, since most of the travelling companions among the Arab tourists were family and children, it would better to include some children's food in the menu.

In relation to Arab tourists' preferences on front office attributes upon arrival at the hotel, the findings indicate that the majority of Arab tourists preferred to have fast check in, friendly and personalized services and courtesy from bellmen and receptionists. This requirement is, in fact in line with what has been obtained by many researchers in this field. Nevertheless, the issue that needs to be addressed is related to language, and from this study it is believed that most of the Arab tourists lack proficiency and understanding of the English language. This has created communication barriers especially in dealing with hotel employees and the public. Owing to these barriers, the Arabs might perceive those hotel employees and other personnel with whom they come in contact as not friendly enough, or less attentive towards them. If these matters are taken lightly by the hotel operators, in the long term it will eventually reduce room occupancy in those particular hotels. In relation to this, since Malaysia is starting to receive a majority of Arabs tourists it is suggested that the hotel operators need to make their premises known by providing personnel who are able to speak Arabic, particularly in the customer contact areas such as the front office and the restaurant. For instance, one or two personnel could be sufficient, or they could hire someone during the peak period. In fact, travel agencies and tour operators should also consider having such services in their operations. The ability to communicate in and to understand their language can have a profound effect on the hotel image and sustain the market. In sum, providing better service could mean return visits to that particular hotel in the near future could be assured.

Although, this study has made a significant contribution to the understanding of the Arab travelling pattern and preferences in hotel restaurant food and front office attributes, there are some flaws or limitations which could lead to further research. First and foremost, a limitation relates to samples used in this study. As only five hotels in the area of Kuala Lumpur's Golden Triangle participated in this study, the overall findings certainly cannot be generalised and represent the whole country. This restriction was due to budget constraints and limited time. Therefore, if more time and a larger budget were allocated, the replication of such research could be carried out in a broader scope with more hotels throughout Malaysia involved. Further research could also be carried out in various categories of hotels throughout the country. The second limitation relates to data analysis. The descriptive analysis undertaken by the researcher has given less statistical evidence to collaborate with the findings. The result would be stronger if a scientific approach to statistics, either a parametric or non parametric procedure, were employed in the data analysis section. We suggest that future research should move towards a more statistical analysis rather just a descriptive analysis. Finally, limitations pertain to the instrument. There were only a few item used to measure tourists' preferences in hotel restaurant food and front office attributes. More attributes pertaining to these variables could be used in future research.

\section{Conclusion}

From the overall implications of this study, it could be concluded that a strong relationship between government, local authorities, private agencies and hotel operators should be fostered to ensure that tourists' needs, especially in potential markets in this case Arab tourists, can be fulfilled. In other words, all the above-mentioned bodies should support one other to improve all types of services provided to the tourists. Failure to develop such a unity of approach would mean that the intention of the central government to see Malaysia as a world famous tourist destination, as well as other missions cannot be achieved.

\section{References}

Basala, L.S. \& Klenosky, D.B. (2001). Travel style preferences for visiting a novel destination: A conjoint investigation across the novelty familiarity continuum. Journal of Travel Research, 40:172-182. 
Cavana, B., \& Dalahaye, B. (2001). Applied business research: Qualitative and quantitative methods. Brisbane: John Wiley.

Crompton, J.L. (1979). Motivation of pleasure vacation. Annals of Tourism Research, 6(4): 408-424.

Din, Kadir H. (1989). Islam and tourism - patterns, issues, and options. Annals of Tourism Research, 16, 542-563.

Graburn, N.H. (1977). Tourism: The sacred journey in host and guests: The Anthropology of Tourism, In Valene Smith. (Ed). 17-31. Philadelphia: University of Pennsylvania Press.

Hamarneh, A.A., \& Steiner, C. (2004). Rethinking the strategies of tourism development in the Arab world after September 11, 2001. [Online] Available: http://www.islamictourism.com(Retrieved from June, 2005)

Houellebecq, M. (2001). Platform. Original French title: Plateforme, Paris: Flammarion, 306-321.

Malaysia Hotel Association. (2004). Malaysian Association of Hotels: Annual Report (2004).

New Straits Time, Malaysia. (2007). Malaysia an ideal tourist's destination. (2007, March 8).

Pearce, P.L., \& Caltabiano, M.L. (1983). Inferring travel motivation from travellers' experience. Journal of Travel Research, 22, (Fall), 16-20.

Polunin, I. (1989). Japanese travel boom. Tourism management, 10 (1): 4-8.

Ritter, W. (1989). On desert and beaches: Recreational tourism in the Muslim world. Tourism Recreation Research, 14, (2), 3-10.

Tourism Malaysia. (2003). Annual report on profile of tourists by selected market. Planning and Research Division.

Tourism Malaysia. (2004). Annual report on profile of tourists by selected market. Planning and Research Division.

Tourism Malaysia. (2006). Annual report on profile of tourists by selected market. Planning and Research Division.

Yuan, S., \& Mcdonald, C. (1990). Motivational determinants of international pleasure time. Journal of Travel Research, 4 , Fall, 42-44. 